\title{
«Либералы» versus «демократы»: идейные траектории постсоветской трансформации в России ${ }^{1}$
}

\author{
В.Я. ГЕЛЬМАН*
}

\begin{abstract}
*Владимир Яковлевич Гельман - кандидат политических наук, профессор, Европейский университет в Санкт-Петербурге; университет Хельсинки. Адрес: 191187, Санкт-Петербург, Гагаринская ул., д. 6/1. E-mail: vgelman@eu.spb.ru

Цитирование: Гельман В.Я. (2020) «Либералы» versus «демократы»: идейные траектории постсоветской трансформации в России // Мир России. Т. 29. № 1. С. 53-79. DOI: $10.17323 / 1811-038 X-2020-29-1-53-79$
\end{abstract}

В статье рассматривается борьба идей модернизации в проиеесе трансформаџии России в 1980-1990-х годах. Анализируются генезис и эволюиия двух основных идейных течений этого периода: «либералов», приоритетом которых стало строительство эффективной рыночной экономики, и «демократов», выступавщих за становление демократических свобод и институтов. Основное внимание уделено истокам и противоречиям данных идейных течений, причинам и следствиям разногласий между ними, а также воздействию идей модернизащии на ход и результаты общественных преобразований в России. Показано, что важнейшей причиной идейных размежеваний и политического конфликта российских «либералов» и «демократов» в 1990-е годы стали межпоколенческие противоречия шестидесятников и семидесятников, чьи политические установки, жизненный опьт и восприятие проблем странь существенно различались. Если «демократыл представители поколения шестидесятников - имели смутные представления о переходе к рыночной экономике и уделяли мало внимания этим аспектам преобразований, то многие «либераль» - семидесятники - весьма скептически воспринимали демократизацию и видели в ней угрозы рыночнылм реформам. Эти расхождения, помноженные на политические конфликты 1990-х годов, послужили причиной «развода» между этими реформаторскими идейныли течениями. В результате обе стороны конфликта - «либералы» и «демократы» - потерпели тяжелое политическое поражение, что оказало сущеественное влияние на российский идейный и политический ландшафт начала XXI века.

1 Статья опубликована в рамках проекта НИУ ВШЭ по поддержке публикаций авторов российских образовательных и научных организаций «Университетское партнерство». 
Ключевые слова: политические идеи, посткоммунистическая трансформация, Россия, либерализм, демократия, рыночные реформы

Какова роль идей в процессах модернизации в целом и в постсоветской российской модернизации в частности? Специалисты расходятся в оценках вклада идей в строительство новых институтов и практик в различных странах в те или иные исторические периоды и по-разному отвечают на вопрос о том, являются ли идеи причиной преобразований или же выступают их следствием. Однако применительно к анализу процессов политической, экономической и социальной трансформации в постсоветской России, скорее, преобладает представление о том, что идеи носили вторичный характер по отношению к интересам ключевых игроков [Травин, Гельман, Заостровцеев 2017]. Означает ли это, что роль идей в России конца XX - начала XXI в. была и остается настолько незначительной, что ею можно пренебречь, поставив в фокус политического анализа деятельность оппортунистов - политиков и бизнесменов, которыми движут исключительно корыстные мотивы и которые добиваются или не добиваются своих целей, не опираясь на идеи или же используя их исключительно как орудие манипуляций? Хотя опыт постсоветской России демонстрировал немало примеров такого рода [Hoffman 2002; Dawisha 2014; Авен 2018], было бы неверным сводить процессы экономических и политических изменений в нашей стране исключительно к борьбе противоборствующих интересов, полностью выводя за скобки идеи: эти измерения в ходе преобразований дополняют, но не замещают друг друга.

Между тем идеи и идеологии (далее эти термины будут употребляться как синонимы) в процессе модернизации в современной России демонстрировали существенное отличие от идей в ряде других посткоммунистических стран, разрешавших сходную «дилемму одновременности» политических и экономических преобразований [Offe 1991] в тот же период времени. В странах Восточной Европы идеи строительства демократии (здесь и далее обозначены как демократические идеи) и перехода к рыночной экономике (здесь и далее обозначены как либеральные идеи) взаимно дополняли и усиливали друг друга в процессе посткоммунистической трансформации от падения прежних режимов до вступления в Европейский союз [Appel, Orenstein 2016], помогая этим странам решать ключевые задачи преобразований в относительно короткие сроки. Однако в России 1990-х гг. либеральные и демократические идеи (и их носители) вступили в острое противоречие: представления о том, что путь страны к экономическому благополучию может и должен обойтись без демократии, которая способна создать помехи экономическим реформам, если не обратить их вспять, не только преобладали в публичных дискуссиях, но и влияли на принятие политических решений. В результате идеи строительства демократии сначала оказались за рамками перечня приоритетов политической повестки дня, затем были принесены в жертву идеям экономической модернизации страны, а в 2000-2010-е гг. оказались исключенными из меню опций правящих групп. Напротив, идеи строительства эффективной рыночной экономики доминировали в официальном дискурсе правящих групп и служили важным ориентиром при выработке политического курса как в 1990-е, так и в 2000-е гг., хотя их влияние со временем ослабевало. Наконец, в 2010-е гг. они также были сняты с политической повестки дня, и на сегодняшний день их воздействие на политические процессы и политический курс в России незначительно. 
Чем объяснить «развод» демократических и либеральных идей в постсоветской России, который произошел в 1990-е гг., и их последующий упадок в 2000-2010-е гг.? И был ли обусловлен нынешний упадок и демократических, и либеральных идей в России их «разводом», который произошел в 1990-е гг.? Поиски ответов на эти вопросы требуют переосмысления роли идей в процессе модернизации России и тех траекторий, которые демонстрировали демократические и либеральные идеи на протяжении последних трех десятилетий. Эти идеи продвигались их носителями - политиками, аналитиками, публицистами (в рамках данной работы обозначенных как «демократы» и «либералы») ${ }^{2}$, роль которых в формировании, эволюции и борьбе идей в конце 1980-х - начале 1990-х гг. была неоценима. Данная статья призвана обозначить проблемы генезиса и эволюции этих двух основных идейных течений российской модернизации конца XX - начала XXI в., противоречий между ними, размежевания в среде их носителей и сторонников, а также воздействия идей посткоммунистической модернизации на ход и результаты общественных преобразований в нашей стране.

Я утверждаю, что «развод» демократических и либеральных идей в России 1990-х гг. не был изначально предопределен, но слабость и неоформленность реформистских идей ко времени перестройки, межпоколенческие противоречия между шестидесятниками и семидесятниками, а также ошибочные оценки и ожидания перспектив страны на фоне высокой неопределенности периода масштабных преобразований наложили неизгладимый отпечаток на идейные траектории «либералов» и «демократов» и усугубляли противоречия между этими течениями.

\section{Идеи и модернизация: случай России}

Различные работы, посвященные постсоветскому политико-экономическому развитию России, основываются на тезисе о том, что в этих процессах идеи играли не слишком значимую роль. Так, Генри Хейл полагает, что постсоветские политики в борьбе за завоевание и удержание власти прежде всего выступали за мобилизацию патрон-клиентских сетей, в то время как в этой борьбе на фоне преобладания клиентелистской политики над программной идеи оставались невостребованными и на уровне спроса, и на уровне предложения [Hale 2015]. Стивен Хэнсон, сравнивая идейный ландшафт посткоммунистической России с Веймарской Германией и со становлением Третьей республики во Франции [Hanson 2010], отмечал, что в российском случае идеи оказались недостаточно оформлены и структурированы, что, по его мнению, негативно повлияло на формирование партийной системы в стране. Сходное мнение высказывал и автор этих строк, утверждая, что после распада СССР идеи слабо повлияли на трансформацию российского политического режима, исход которой прежде всего был обусловлен характером борьбы элит за власть [Gel'man (1) 2015].

2 Здесь и далее эти термины в кавычках используются как самоназвания. Вопрос о соответствии взглядов и действий российских «либералов» и «демократов» соответствующим доктринам выходит за рамки настоящей статьи (критику см.: [Капустин 1995; Lukin 2000]). 
Означает ли это, что в ходе анализа посткоммунистической модернизации в России идеями можно пренебречь? Такого рода вердикт означал бы, что вместе с водой выплеснули и ребенка. Идеи были и остаются важны для определения приоритетов политического курса и государственного строительства в стране, они весьма значимы в отдельных «точках перелома», когда политики делали стратегический выбор в пользу тех или иных вариантов дальнейшего развития страны. Наконец, сам по себе факт низкого влияния идей на процессы преобразований в стране также нуждается в объяснении. Если идеи воздействовали на поведение представителей элит и масс в ходе модернизации различных стран и служили важным двигателем преобразований периода перестройки, когда дискуссии сторонников различных реформистских идей захлестывали CCCP [Urban 1997; Reddaway, Glinski 2001; Шейнис 2005; Сигман 2014], то почему на протяжении последующего десятилетия и далее значимость этих идей деградировала?

Определение места идей в процессах модернизации в России прежде всего требует уточнения понятий. Идеи в рамках данной статьи рассматриваются инструментально, то есть не как набор неких разработанных политических доктрин, а как способ восприятия проблем. Идеи значимы для процесса модернизации в силу своих позитивных и нормативных функций: они помогают элитам и массам сформулировать свои представления о желаемом общественном устройстве и о способах его достижения [North 1981, p. 49], вынести суждение о соответствии статус-кво этим представлениям и минимизировать количество информации, необходимой для принятия решений (что особенно значимо в условиях неопределенности). Таким образом, идеи позволяют акторам создать и поддерживать картину мира, в рамках которой они предпринимают действия на основе восприятия информации. В русле этого подхода, например, В.В. Радаев анализировал процесс смены хозяйственных идеологий в России 1980-1990-х гг. [Радаев 1998, с. 276-306], а коллектив с участием автора этих строк - идеологии в сфере реформ местного самоуправления в России [Гельман, Рыженков, Белокурова, Борисова 2002].

Из этого понимания идей следует, что в рутинных условиях спрос на них не столь велик: элиты и массы могут следовать прежним схемам на протяжении довольно длительного времени, а производители идей - политики, эксперты и автономные интеллектуалы - воспроизводить ранее сложившиеся суждения, лишь отчасти модифицируя их. Однако в периоды бурных перемен, которые характерны для радикальных трансформаций, подобных тем, что переживала Россия в 1980-1990-е гг., спрос на новые идеи возрастает. Они возникают и продвигаются производителями и распространителями, которые пытаются как можно выгоднее «продать» их элитам и массам и завоевать поддержку на идейном рынке, вытесняя и/или поглощая конкурентов. Иногда формирование и продвижение новых идей занимают несколько десятилетий (как это произошло с неолиберализмом на Западе [Стедмен-Джоунз 2017]), но порой они переживают этот бум гораздо быстрее. При этом одни возникают спонтанно и эндогенно, в то время как другие импортируются из политических и интеллектуальных контекстов, преломляясь сквозь призму восприятия их реципиентами и порой переживая довольно сильные метаморфозы. Сочетание меняющейся динамики спроса и предложения идей наряду с эффектами деятельности различных агентов по их продвижению во многом определяют исход идейной борьбы в период радикальных перемен. 
Советский Союз вступил в период трансформаций во второй половине 1980-х гг. в довольно своеобразной идейной ситуации. На протяжении долгих десятилетий рынок идей был монополизирован господствовавшей в стране официальной версией марксизма-ленинизма, в то время как альтернативные идеи проникали на этот рынок обходными путями, сталкиваясь с догматизмом со стороны официального истеблишмента, боровшегося против проявлений инакомыслия [Шахназаров 2001; Черняев 2009]. При этом официальные советские догматы настолько обветшали, что уже в период «долгих 1970-х» не могли выполнять позитивные функции: жизнь советского общества кардинально расходилась с официальными нормативными образцами, а построенное на официальной идеологии знание не могло дать убедительных ответов на вопросы о проблемах страны и их возможных решениях. В отсутствие условий для развития социальных и гуманитарных наук, которые могли бы создать интеллектуальную среду для разработки новых идей, востребованных в ходе преобразований, дискуссии о путях развития страны вынужденно ограничивались узкими кругами участников на уровне неформальных кружков и семинаров [Змеиная 2006; Авен, Кох 2013; Clover 2016].

Закрытость СССР от внешнего идейного влияния также была высока - несоизмеримо выше, чем в социалистических странах Восточной Европы. Если такие ключевые фигуры преобразований посткоммунистического периода, как В. Клаус и Л. Бальцерович, задолго до начала реформ регулярно ездили на стажировки и конференции в университеты США и Западной Европы, то советским молодым экономистам приходилось тайком в спецхране читать статьи восточноевропейских коллег, а зарубежные поездки для большинства из них стали доступны лишь в годы перестройки [Змеиная 2006; Васильев 2011]. Поэтому знания советских специалистов о зарубежном опыте модернизации были весьма фрагментарны, а об их вкладе в международную дискуссию говорить почти не приходилось. Как следствие, взгляды российских интеллектуалов на проблемы политического и экономического развития страны и мира за редким исключением были неоформленными и непоследовательными: они подчас сильно менялись под воздействием обстоятельств. Оторванность от международной среды на протяжении долгих десятилетий вызвала у российских интеллектуалов бум представлений об «особом пути» России и об уникальности и специфичности ее прошлого, настоящего и будущего, которые и по сей день преобладают в российской общественной мысли [Травин 2018]. Эти тенденции проявились и в отторжении импорта ряда идей: Иоахим Цвайнерт, анализировавший борьбу экономических идей в ходе рыночных реформ в России, пришел к выводу о том, что в 1990-е гг. многие западные идеи столкнулись со столь сильным сопротивлением внутри страны, что в России (в отличие от Восточной Европы) в последующие десятилетия они так и не укоренились [Zweynert 2018].

Не приходится удивляться тому, что разрушение прежней монополии на советском идейном рынке, произошедшее в конце 1980-х гг., стало своего рода «большим взрывом», который протекал на фоне стремительного изменения ситуации в стране. Запреты пали на фоне резкого взлета спроса на новые идеи и со стороны элит, искавших варианты выхода из нараставшего кризиса, и со стороны общественности [Травин, Гельман, Заостровцев 2017, гл. 1]. В центре внимания оказывались публичные дискуссии интеллектуалов, в то время как дискредитировавшие себя официальные догматы начали утрачивать свою значимость. 
Образовавшийся дефицит на идейном рынке заполнялся спонтанно: импорт идей из-за рубежа сопровождался обращением к идейному наследию прошлого, мода на идеи и их лейблы менялись с невероятной скоростью, а сами идеи подчас не встречали адекватной критической рефлексии. Барьеры выхода на идейный рынок, вчера еще запретительно высокие, вдруг оказались невероятно ничтожными, порой открывая дорогу прежде маргинальным идеям от евразийства до геополитики [Clover 2016]. Тем, кто вырабатывал и/или продвигал новые идеи, не составляло труда донести их до резко расширившейся аудитории: гораздо сложнее оказывалось закрепиться на идейном рынке и оказать не разовое, а систематическое интеллектуальное воздействие как на принятие и выработку политических решений, так и на умы и сердца сограждан.

По мере преобразований, происходивших в стране, спрос на новые идеи начал снижаться, помимо этого, круг проблем кардинально изменился: то, что обсуждалось в конце 1980-х гг., утратило актуальность в середине 1990-х. Политическая повестка дня оказалась насыщена борьбой групп интересов, а идеи оказывали все меньшее воздействие на принятие политических решений. После консолидации авторитарного режима в 2000-е гг. российские власти если и нуждались в идеях, то, скорее, лишь в политико-технологическом ключе - современный российский авторитаризм не привязан к господствующей идеологии [Gel'man (1) 2015], и его руководители могут вполне прагматично использовать различные идеи в своих целях. Общественность, с энтузиазмом воспринимавшая идейную борьбу на рубеже 1980-х и 1990-х гг., со временем стала обращать меньше внимания на идеи и их носителей, которые в свою очередь также эволюционировали. На смену прежней монополии на идейном рынке пришел плюрализм, и в сегодняшней России без труда можно обнаружить сторонников самых разных идейных течений. В отличие от конца 1980-х и начала 1990-х гг. взаимодействие между ними наполнено взаимным игнорированием и параллельным сосуществованием, напоминая ресторан с отдельными столиками и отдельными меню для разных категорий посетителей [Almond 1988], далеким от эффективного диалога. Тем не менее идеи являются значимым фильтром для восприятия проблем российскими элитами и политическими лидерами, которые транслируют свои представления согражданам [Sokolov, Inglehart, Ponarin, Vartanova, Zimmerman 2018; Taylor 2018], и наследие идейной борьбы 1980-1990-х гг. по-прежнему значимо для понимания логики этого восприятия. Да и сами идейные течения этого периода не исчезают с российской политической карты: они меняются со временем, но опыт 1980-1990-х гг. до сих пор служит важнейшей «точкой отсчета» для восприятия как текущих проблем и тенденций, так и рецептов дальнейших перемен (или их отсутствия). Многие производители идей сами были участниками и свидетелями преобразований, и эти знания также наложили значительный отпечаток на восприятие ими проблем страны.

По мнению В.В. Радаева, менее чем за десятилетие (с середины 1980-х до середины 1990-х гг.) в стране сменились четыре господствующие идеологические парадигмы - от социалистической к демократической, затем к либеральной и к консервативной [Радаев 1998, с. 276-306]. Каждый из этих поворотов следовал за сдвигами на политической арене: попытки обновления советской экономической системы (1985-1987/88 гг.), гласность и демократизация в СССР (1987/881990/91 гг.), кризис и крах советской системы и запуск радикальных экономических реформ (1990/91-1993 гг.), исчерпание реформ и последующая постреволюцион- 
ная стабилизация (после 1993 г.). Однако не стоит рассматривать трансформацию идейного ландшафта исключительно как проекцию текущих политико-экономических преобразований в СССР и России. Каждый из «критических моментов» (critical junctures) 1980-1990-х гг. и их последствия стали результатом не только борьбы групп интересов (хотя они безусловно играли значимую роль), но и борьбы идей. Поэтому необходим более пристальный анализ тех идей, которые были ориентированы на реализацию политических и экономических реформ и связаны со строительством демократии и рыночной экономики в нашей стране. Такой анализ призван объяснить, почему (в отличие от многих стран Восточной Европы [Appel, Orenstein 2016]) в России идеи демократизации и рыночных реформ во многом оказались противопоставлены друг другу, что серьезно повлияло на исход политических и экономических преобразований [Åslund 2007; Gel'man (1) 2015].

Говоря о борьбе идей в посткоммунистической России, исследователи уделяли немалое внимание коммунистическим и националистическим идейным течениям [Vujacic 1996; Flikke 1999; Clover 2016; Laruelle 2018]. В то же время работы, посвященные демократическим и либеральным партиям в России, которые по-разному продвигали идеи модернизации страны в 1990-е гг. [Hale 2004; Gel'man 2005; White 2006], лишь в малой мере затрагивали анализ их идеологий. Критические рефлексии со стороны самих «демократов» и «либералов» [Шейнис 2005; Змеиная 2006; Авен, Кох 2013], хотя и содержат немало ценных сведений, лишь отчасти обсуждают вопросы о причинах и следствиях «развода» этих идейных течений. Поэтому следует выявить их генезис и механизмы эволюции на фоне масштабных перемен в России.

Необходимо уточнить, что «либералы» и «демократы» в России выступали своего рода взаимно пересекающимися множествами: одни и те же политики, аналитики, публицисты и другие производители и распространители идей порой одновременно выступали в качестве как «либералов», так и «демократов» и порой даже публично идентифицировали себя и в том, и в другом качестве, а некоторые из них со временем переходили в иные идейные лагеря. Однако в рамках данной статьи эти две категории выделены в аналитических целях как идеально-типические образцы, позволяющие понять логику идейного ландшафта посткоммунистической России.

\section{«Демократы» без либерализма: утраченные иллюзии}

Основными носителями демократических идей в период перестройки в Советском Союзе выступили активные представители поколения шестидесятников - прежде всего те интеллектуалы и общественные деятели, становление политических воззрений и развитие профессиональных и общественно-политических карьер которых пришлись на период между ХХ съездом КПСС и подавлением Пражской весны ${ }^{3}$. Хрущевская оттепель и связанные с ней надежды на успешное развитие страны сформировали и/или существенно изменили мировоззрение шестидесятников [Барбакадзе 2007]. Однако период застоя, охватившего страну во время

3 Здесь и далее использованы материалы ранее опубликованной статьи [Гельман, Травин 2013]. 
правления Л.И. Брежнева, не только надолго задержал восхождение многих представителей этого поколения по карьерной лестнице, но и сделал неактуальными идеи, сформированные в период оттепели: поколение шестидесятников пережило своего рода «замораживание» на два десятилетия [Zubok 2009, ch. 9]. Когда в период перестройки шестидесятники вышли на авансцену общественной и политической жизни страны, то казалось, как будто Советский Союз вернулся вдруг на некоторое время в эпоху оттепели. «Дети XX съезда» заняли ведущие позиции во властных структурах, доминировали в перестроечной журналистике и предлагали ключевые концепции развития общества. Те, кто присоединился к «демократам», во многом ориентировались на шестидесятников и отчасти до сих пор следуют заложенным ими интеллектуальным и идейным традициям.

Для «демократов» времен перестройки основной целью была дальнейшая реализация программы оттепели - политический плюрализм в СМИ и на уровне принятия решений, осуждение политических репрессий, расширение свобод и устранение многочисленных запретов советской эпохи (цензура, ограничения зарубежных поездок). На первом этапе предложения были достаточно робкими [Афанасьев 1988], в то время как наступившие перемены оказались слишком внезапными: демократизация и свободные выборы быстро привели к расширению прежних пределов мечтаний, и на время показалось, что достаточно лишь преодолеть последние барьеры, чтобы, говоря словами одного из перестроечных публицистов, «стать Европой» [Баткин 1988]. Но, столкнувшись с реальными проблемами трансформации, «демократы» оказывались не в состоянии сформулировать осмысленные и реалистичные позитивные альтернативы стремительно ухудшавшемуся статус-кво [Fish 1995; Шейнис 2005]. Их восприятие информации во многом отражало систему координат, заданную коллективным опытом периода оттепели со всеми присущими ей достоинствами и недостатками. Эта система изначально предполагала постепенные и частичные изменения сложившихся в СССР политических и экономических отношений (при приоритете первых над вторыми), а не их полный пересмотр и замену, однако к такому повороту событий многие «демократы» оказались не готовы. Она также не учитывала изменения, произошедшие со времен оттепели в стране и мире: шестидесятники шли в перестройку как в последний бой своей (уже прошедшей) войны, вооруженные во многом устаревшими представлениями. Неудивительно, что этот бой в конечном счете был ими проигран, а провозглашавшиеся ими идеи оказались дискредитированы. По своему опыту и мировоззрению «демократы» были недостаточно готовы использовать возможности трансформации общества, предоставленные им перестройкой.

Прежде всего эволюции идей шестидесятников препятствовало отсутствие возможности для превращения слов в дела. Дискуссии о преобразованиях в СССР, которые велись до середины 1980-х гг., практическим ничем не заканчивались. Для их участников четкое формулирование своей позиции, изложение взглядов и их доведение до узкого круга читателей превращались в самоцель. Распространение идей было важнее их воплощения в жизнь: об их практическом применении шестидесятники вряд ли думали всерьез, поскольку времена будущих реформ казались им невероятно далекими. Поэтому все силы, талант и страсть шестидесятников обращались на то, чтобы перехитрить советский режим и высказать свои мысли. Когда же час реформ пробил, многие «демократы» не смогли выработать 
реальные альтернативы тому курсу, который пытались проводить руководители страны, и тем более не были готовы к воплощению их в жизнь. К тому же далеко не все «демократы» смогли взять на себя личную ответственность за принятие и реализацию ключевых решений. Характерно, например, что в 1992 г. в поисках авторитетной фигуры, способной заменить Е.Т. Гайдара на посту премьерминистра России, представители команды Б.Н. Ельцина обратились к академику Ю.А. Рыжову. Яркий интеллектуал-шестидесятник, в 1991 г. назначенный послом России во Франции, ответил отказом, не пожелав менять статусный пост на нелегкую работу по выведению страны из кризиса [Авен, Кох 2013]. Хотя многие рядовые активисты «демократов», особенно в провинции, явно не дотягивали по своему уровню до того, чтобы успешно участвовать в принятии и реализации значимых решений [Fish 1995; Lukin 2000], наиболее способные из их числа позднее сами многому научились и приобрели солидные управленческие навыки (впрочем, такие случаи оказались редкими).

Прежний опыт оттепели и крах внезапно дарованных и позднее отобранных свобод породили у «демократов» своеобразные комплексы и синдромы. Речь шла не только о петициях, адресованных наверх в качестве способа решения проблем, но и о страхах перед реальными или вымышленными угрозами лишиться свобод. Многие «демократы» перестроечной поры почти панически боялись любых выступлений со стороны радикальных коммунистов и/или русских националистов, хотя эти течения не пользовались существенным спросом на нарождавшемся в те времена идейном рынке. Транслируя свои идеи на публику, «демократы» воспроизводили бинарную оппозицию «против номенклатуры КПСС - за демократию», давая немало поводов для критических высказываний в свой адрес в части того, что демократия воспринималась ими как власть «демократов» [Lukin 2000]. Хотя демократия преподносилась как необходимое условие устранения текущих вызовов, представления «демократов» о способах их урегулирования были весьма размытыми. В частности, они предлагали решение проблем национально-государственного устройства СССР в духе «ребята, давайте жить дружно» без серьезного понимания породивших их причин [Сахаров 1989], а лозунг, выдвинутый осенью 1991 г. одним из лидеров «демократов» Ю.Н. Афанасьевым в ответ на вызовы сепаратизма в России - «Россия единая, но делимая», поставил в тупик даже самих активистов [Reddaway, Glinski 2001].

Экономическая повестка дня в мировоззрении «демократов» носила периферийный характер. Поддерживая переход страны к рыночной экономике (по принципу «за все хорошее, против всего плохого»), «демократы» по большей части имели смутные представления о путях решения этой проблемы. Поэтому порой они ориентировались на устаревшие образцы (как венгерский «гуляш-социализм» или югославское производственное самоуправление) и/или предполагали соединение несовместимых элементов, и в целом уровень восприятия нараставших экономических проблем в стране не выдерживал критики [Сонин 2007]. Так, программа блока «Демократическая Россия» в ходе кампании по выборам народных депутатов РСФСР 1990 г. сочетала в себе призывы к равенству всех форм собственности и требования замораживания розничных цен на период перехода к рынку. По свидетельству одного из авторов документа В.Л. Шейниса, программа, по сути, представляла собой компиляцию предложений, которые выдвигались различными демократическими кандидатами [Шейнис 2005, т. 1, с. 255-259], 
вообще без какого-либо намека на механизмы практической реализации. Нереалистический характер таких положений уже тогда подвергался справедливой критике, но она не обсуждалась всерьез. История не терпит сослагательного наклонения, и мы никогда уже не узнаем, какую экономическую политику стали бы проводить «демократы», если бы в 1991 г. рычаги власти оказались у них в руках, но следует согласиться с утверждением, что «демократы» в своих представлениях о реформах в экономике (и не только) исходили из желаемого, а не из возможного [Васильев, Львин 1989].

По существу, политическая программа «демократов» оказалась выполнена в августе 1991 г., причем не столько в результате их собственных усилий, сколько в силу непреднамеренных последствий непродуманных действий советского руководства во главе с М.С. Горбачевым. Крушение прежнего режима, ставшего столь внезапным, поставило под вопрос идеи «демократов». К выработке новой повестки дня большинство из них оказались явно неспособны [Reddaway, Glinski 2001; Шейнис 2005, т. 2]. Первые шаги посткоммунистической России вызвали у ряда «демократов» глубокие разочарования [Буртин 1992], а развитие событий после 1993 г. выталкивало их в сторону принципиальной политической оппозиции российскому режиму [Gel'man 2005]. Идейное лидерство «демократов» было перехвачено представителями другого течения - «либералами», по своему багажу, приоритетам и подходам кардинально отличавшимися от своих предшественников: на смену отцам-шестидесятникам пришли дети-семидесятники.

Разграничительная линия этих поколений была достаточно зыбкой, и хотя 1968 г. - разгром Пражской весны и окончание оттепели в СССР - явил собой очевидную, четко очерченную границу, формирование личностных приоритетов носило длительный по времени характер и не было линейным и однозначным, да и взгляды многих россиян порой менялись во времени довольно существенно [Sokolov, Inglehart, Ponarin, Vartanova, Zimmerman 2018]. Среди семидесятников можно было обнаружить тех политиков, аналитиков и публицистов, чье восприятие мира и выстроенная в соответствии с ним система координат были ближе к шестидесятникам (противоположные примеры встречались куда реже). Межпоколенческий разрыв сыграл немалую роль в дальнейшем расхождении траекторий российских «демократов» и «либералов».

\section{«Либералы» без демократии: политика без иллюзий}

Семидесятники формировались в условиях «долгих 1970-х», в период между крахом оттепели и началом преобразований эпохи перестройки, отличавшийся не только дефицитом значимых преобразований в СССР и стремлением законсервировать статус-кво в политике и экономике, но и отсутствием надежд на «светлое будущее», которые были характерны для времен юности и молодости шестидесятников. Новое поколение должно было учиться жить сегодняшним днем в рамках тех правил игры, которые задавали лидеры страны, что способствовало развитию прагматизма, а порой и цинизма. На фоне равнодушия и/или презрения к официальной коммунистической идеологии этот прагматизм принимал весьма разнообразные формы, и надо было не мечтать о совершенствовании или тем более 
трансформации советской системы, не строить «воздушные замки», а добиваться конкретных результатов «здесь и сейчас». При этом зачастую высокая квалификация, успешная карьера и безразличие к коммунистической идеологии вполне сочетались между собой [Yurchak 2005; Гельман, Травин 2013].

Однако безразличие семидесятников к официальной идеологии отнюдь не означало отсутствия чувствительности к любым идеям. Просто сами идеи воспринимались ими через призму прагматических интересов, то есть не в нормативном, а в позитивном ключе - не как абстрактные ориентиры развития всего общества, а как средства достижения их собственных целей. Поэтому если риторика «демократов»-шестидесятников изобиловала противопоставлениями власти и общества [Афанасьев 1988], то в воспоминаниях «либералов»-семидесятников для общества места почти не находилось вообще [Змеиная 2006; Авен, Кох 2013]. Их заботы касались экономики, а политика (в смысле politics) в лучшем случае рассматривалась как набор условий и ограничений для проведения политического курса (в смысле policy), а в худшем - не вызывала интереса. Прагматическое восприятие идей определяло и отношение к преобразованиям времен перестройки: в отличие от шестидесятников с их неоправданными ожиданиями, у многих семидесятников никаких иллюзий не было изначально.

Семидесятники поддерживали идеи рыночных реформ, видя в них средство избавления от неэффективности советской экономики и повышения жизненного уровня: эти приоритеты наряду с наработанными знаниями в сфере экономики и сделали их «либералами». Именно экономическая повестка дня преобладала в их дискуссиях периода перестройки [Змеиная 2006; Васильев 2011] и оставалась в центре дебатов в последующие десятилетия [Авен, Кох 2013]. Вся остальная система координат (включая сферу политики, но не ограничиваясь ею) оказалась почти полностью привязана в восприятии «либералов» к категориям экономической эффективности [Капустин 1995; Радаев 1998, с. 276-306]. При этом идеи демократии, вышедшие на передний план в конце 1980-х, были восприняты сугубо инструментально и как минимум неоднозначно, что отчасти отражало общие тенденции посткоммунистического неолиберализма [Appel, Orenstein 2016]. Если политическая либерализация как средство снятия наиболее бессмысленных и раздражавших запретов (ограничения доступа к информации, возможностей поездок за рубеж и так далее) сама по себе ими одобрялась, то представления о демократии как о власти народа, разделении властей, защите прав меньшинств вызывали у «либералов» (в отличие от «демократов») смешанную реакцию. Более того, на фоне усугублявшегося кризиса прежней системы в период перестройки длинные и подчас бесплодные дебаты на общеполитические темы все чаще воспринимались ими как бесполезная «говорильня», а многие шаги советского руководства в сфере экономической политики вызывали глубокие разочарования [Aslund 1991; Miller 2016].

В конце 1980-х гг. различия в восприятии и приоритетах (политика у «демократов» vs экономика у «либералов») стали причиной идейных размежеваний: там, где «демократы» видели противостояние «хорошего» и «плохого», воспринимая перестройку как столкновение ее идейных сторонников и противников [Заславская 1988], «либералы» акцентировались на борьбе «плохого» с «худшим», то есть на борьбе между нежеланием ничего менять как в экономике, так и в управлении страной, с одной стороны, и некомпетентными попытками исправить ситуацию 
с помощью полумер, лишь усугублявших кризис, с другой [Gaidar 2007]. Если «демократы» воспринимали массовую мобилизацию общественных движений перестроечной поры как признак демократизации, то для «либералов» она выглядела как один из признаков «смут» и источник рисков для экономики и управления государством [Гайдар 2009]. Эти различия в восприятии вызывали у «либералов» стремление к поиску альтернативных решений в сфере politics. Неудивительно, что в противоположность «дилемме одновременности» частью «либералов» были подхвачены тезисы о необходимости рыночных реформ в условиях жесткого авторитарного режима.

Впервые идея о необходимости и даже желательности авторитаризма как инструмента для реформирования советской системы вошла в публичный оборот в СССР усилиями А.М. Миграняна (его интервью вместе с И.М. Клямкиным, опубликованное в «Литературной газете» под характерным заголовком «Нужна железная рука?» [Мигранян, Клямкин 1989]). Эта дискуссия (как и другие эпизоды публичной полемики того времени) не оказала значимого влияния на политическую повестку дня, и рассматривать ее как предтечу авторитарного поворота в России после распада CCCP [Sautman 1995] было бы неоправданным преувеличением. Однако табу на обсуждение авторитарных решений проблем страны оказалось снято: если для «демократов»-шестидесятников, переживших сталинизм и его развенчание во времена оттепели, связанный с репрессиями авторитаризм рассматривался как однозначно неприемлемое решение, то для «либералов»-семидесятников оно было не более чем одной из возможных опций для проведения экономических преобразований.

В том же 1989 г. С.А. Васильев и Б.М. Львин отмечали нарастающий разрыв между острой необходимостью в проведении глубоких и болезненных экономических реформ и намерениями властей и демократической общественности растянуть этот процесс во времени, опираясь на мягкие и не оправдывающие себя методы их проведения. По мнению авторов, у руководства СССР возрастали стимулы к тому, чтобы прибегнуть к авторитаризму во имя проведения реформ, в то время как на уровне советских республик могли возникнуть стимулы к демократизации с опорой на национализм [Bacuльев, Львин 1989]. В плане выработки policy recommendations сходные соображения легли в основу «Аналитической записки по концепции перехода к рыночной экономике в СССР», подготовленной в марте 1990 г. Ассоциацией социально-экономических наук ${ }^{4}$ [Жестким курсом 1990]. Авторы этого документа предлагали широкий набор авторитарных мер, призванных предотвратить угрозы популистской экономической политики и массовых протестов под антирыночными лозунгами и исходили из неизбежности и безальтернативного характера авторитаризма во имя рыночных реформ. Такая комбинация политических и экономических условий для большинства посткоммунистических стран была нехарактерной: авторитаризм почти нигде не способствовал рыночным успехам [Hellman 1998; Frye 2010], и опыт разворачивавшихся на глазах «либералов» рыночных реформ в Восточной Европе [Змеиная 2006; Авен, Кох 2013] как раз свидетельствовал об ином. Также примечательно и то, что переход к рыночной экономике рассматривался авторами «Аналитической записки» как одноразовый «большой скачок» с бинарным возможным исходом (либо успех, либо полный провал), а промежуточные и/или компромиссные варианты ими вообще не обсуждались.

4 Создана в 1989 г. и возглавлялась Анатолием Чубайсом. 
К тому моменту образцы для подражания «либералов» начали претерпевать изменения. Уже в 1989 г. В.А. Найшуль призывал ориентироваться в ходе рыночных реформ не на Венгрию и Югославию и даже не на страны Западной Европы с их зарегулированной экономикой и этатизмом, а, скорее, на опыт США [Найшуль 1989]. В том же ряду поисков образцов для подражания стояла и поездка группы российских «либералов» в Чили, организованная В.А. Найшулем в апреле 1991 г. (ее венчала встреча участников с Пиночетом, к тому времени вынужденным уйти в отставку под давлением демократизации). Многочисленные позитивные отзывы об успехах чилийских реформ, подкрепленные фотографиями в компании бывшего диктатора, в немалой мере способствовали инверсии восприятия Пиночета. Бывший главный злодей в глазах советской пропаганды на какое-то время превратился в главного реформатора, хотя в реальности чилийский опыт реформ был более сложным и многогранным и по многим параметрам служил исключением из общих правил [Дерлугьян 2010; Травин, Маргания 2011, с. 587-600]. Несмотря на то, что критики утверждали, что, съездив в Чили, будущие российские реформаторы стремились использовать опыт Пиночета на практике [Игрунов 2015], эта мода оказалась краткосрочной, и по прошествии лет сами участники поездки вспоминали о ней без особых эмоций [Змеиная 2006; Львин 2006]. Но миф о Пиночете как «модельном» реформаторе (и, соответственно, о «чикагских мальчиках» как ролевой модели для российских «либералов») зажил своей жизнью. Краткое увлечение Пиночетом не было забыто российскими «либералами»: позднее некоторые из них пытались искать заветные черты «силовика»-реформатора и в В.В. Путине.

Не будет преувеличением утверждать, что к моменту начала экономических реформ в России осенью 1991 г. российские «либералы» имели достаточно целостное представление о том, как следует осуществлять преобразования, какую экономику надо построить в результате реформ и какое политическое устройство необходимо и желательно. Демократия рассматривалась ими не столько как препятствие на пути рыночных реформ, сколько как предмет роскоши, обретение которого России следовало отложить на потом, а имманентно присущие демократии «дефекты» - электоральная подотчетность, риски популистской экономической политики и ограничения «свободы рук» правительства - воспринимались как не совместимые с рыночными реформами. Позднее многие «либералы» [Улюкаев 1995, с. 8; Чубайс 2008] сохранили и даже упрочили понимание мира политики, которое сформировалось накануне распада СССР. Более того, это восприятие, сводившееся к формуле «либеральным реформам в экономике - твердое “да", демократии в политике - "вообще-то да", но не сейчас и не в первую очередь», спустя годы и десятилетия фиксировалось в многочисленных программных документах российских властей («Стратегия-2010», «Стратегия-2020» и т.д.), в разработке которых «либералы» принимали самое активное участие.

\section{Две дороги к одному обрыву}

1991 год ознаменовал начало смены поколений в российской политике. «Либералы»-семидесятники в ходе гайдаровских реформ стали выдвигаться на ведущие позиции в правительстве и в публичной сфере, а «демократы»-шестидесятники 
начали движение по нисходящей траектории, и не только в силу возрастных ограничений. Повестка дня «демократов» казалась тогда выполненной, а «либералы» выглядели именно теми, кто только и мог решить задачи трансформации. Не вдаваясь в полемику о том, возможны ли были в 1990-е гг. иные варианты проведения экономических и политических реформ и можно ли было осуществить их более успешно, чем это сделали российские «либералы», необходимо отметить, что многие черты поколения семидесятников наложили немалый отпечаток на вектор преобразований. В то время как продолжительные дискуссии уступили место конкретным мерам, выбор приоритетов и средств достижения целей осуществлялся ими исходя из прагматической повестки дня: представления не о желаемом, а о возможном, краткосрочный горизонт планирования, гибкость и склонность к компромиссам сочетались с умением добиваться поставленных целей. Кроме того, неудачный опыт предшественников, «демократов»-шестидесятников, которые в период перестройки упустили свой последний шанс на преобразование прежней системы, давал «либералам»-семидесятникам ясный сигнал, как именно поступать не следует. В такой ситуации подходы «отцов» и «детей» почти неизбежно оказывались зеркально перевернутыми, в том числе в отношении выбора последовательности преобразований экономической и политической систем: «либералы» пожертвовали демократией ради рыночных реформ.

Когда в конце 1991 г. Россия «заморозила» все существовавшие на тот момент политические институты и прежнее национально-государственное устройство страны, приоритетом № 1 для политических элит (и для общественного мнения) оказалось проведение в стране экономических преобразований. Надежды «либералов», которые поддержали эти шаги, были связаны с тем, что радикальные экономические реформы за относительно недолгий промежуток времени могли бы вывести страну из кризиса, после чего настало бы время для демократизации политического режима [Авен, Kox 2013], но этим надеждам было не суждено сбыться: правительству России не удалось быстро добиться финансовой стабилизации, реформы российской экономики оказались крайне растянуты во времени, а трансформационный спад экономики был насыщен драматическими поворотами и завершился дефолтом и девальвацией российской валюты. Политический контекст экономических преобразований в России 1990-х гг. мало походил на опыт посткоммунистических реформ в Восточной Европе [Appel 2004]. Отчасти эти различия были связаны с тем, что после распада СССР силовой и распределительный потенциал государства оказался резко ослаблен, в то время как спад производства был гораздо более сильным и длительным, чем у соседей по бывшему коммунистическому блоку.

Немалую роль сыграли и субъективные факторы, связанные с политической тактикой реформ, которые проводились самими «либералами» и их союзниками [Shleifer, Treisman 2000]. Эта тактика, по сути, представляла собой цепь тактических соглашений не с теми, кто проиграл от первого этапа реформ, а, напротив, с теми, кто от него выиграл и оттого не был заинтересован в дальнейших преобразованиях [Hellman 1998], - олигархами, региональными лидерами и другими соискателями ренты. «Либералы»-семидесятники (в отличие от шестидесятников) были готовы быстро адаптироваться к меняющимся обстоятельствам и при необходимости легко шли на компромиссы для того, чтобы добиться возможного, ориентируясь на краткосрочные задачи, а не на заоблачное «светлое будущее». 
Отчасти этим обстоятельством можно объяснить отмечавшийся специалистами и самими участниками [Змеиная 2006; Авен, Кох 2013] феномен российских реформ 1990-х гг.: по ряду важных вопросов реформирования экономики команда Е.Т. Гайдара легко сдавала свои позиции, надеясь на тактический выигрыш от компромиссов и стремясь получить желаемый результат в иных сферах. Так, под давлением сильных лоббистов она согласилась отступить от антиинфляционного курса, мотивируя это, в частности, необходимостью сохранить свои позиции при проведении приватизации предприятий. Но и курс приватизации [Boycko, Shleifer, Vishny 1995] также подвергся компромиссам и привел к тому, что большие преимущества в сравнении с первоначальными намерениями получили инсайдеры трудовые коллективы предприятий и возглавляющие их директора [Barnes 2006]. «Умиротворение» узких групп интересов, которые преследовали цели, связанные с извлечением ренты [Åslund 2007], обусловило высокие политические издержки проведения реформ (как для самих реформаторов, так и для страны в целом), а последующее изменение курса правительства в 2000-е гг. стало причиной пересмотра ряда результатов преобразований [Yakovlev 2006; Frye 2017]. Иначе говоря, тот курс, который проводили «либералы» в 1990-е гг., во многом противоречил их собственным идеям, сформулированным до начала экономических реформ.

Отчасти подоплека такой непоследовательности была связана с тем, что изначально сами «либералы» приняли на себя роль технократов-реформаторов, не стремясь выступать в качестве независимых акторов на российской политической сцене и не включаясь в публичную борьбу за власть, что делало их позиции весьма уязвимыми [Gel'man 2018]. Когда же в ходе парламентских выборов 1993 г. этот выход, наконец, состоялся, «либералы» столкнулись не только с тем, что их идеи и лидеры пользовались ограниченной поддержкой, но и с острой конкуренцией со стороны «демократов», которые после 1991 г. вроде бы оказались списаны со счетов. Точкой разрыва были события сентября-октября 1993 г., ставшие пиком политической поляризации в стране, нараставшей с 1990 г. [Рогов 2018]. «Либералы», одобрявшие действия Б.Н. Ельцина, активно поддержали роспуск российского парламента и силовые меры его подавления, воспринимая эти шаги как устранение препятствий на пути реформ. В то же время «демократы» если и не явно осудили действия Б.Н. Ельцина, то по меньшей мере отмежевались от них.

Идейное расхождение между «либералами» и «демократами» оформилось и на политическом уровне - между блоком «Выбор России» (ВР) и его преемниками «Демократическим выбором России» (ДВР) и «Союзом правых сил» (СПС), с одной стороны, и «Яблоком», с другой. Созданный под руководством ведущих «либералов» «Выбор России», претендовавший в ходе выборов 1993 г. на роль партии власти, смог присвоить себе часть организационных ресурсов прежнего демократического движения, но выступил на выборах не слишком удачно [McFaul 1998]; после утраты его представителями ряда правительственных постов блок был преобразован в партию «Демократический выбор России». Партия представляла собой типичную «полуоппозицию» [Gel'man 2005], сочетая умеренную критику отдельных аспектов правительственного курса с безоговорочной поддержкой Кремля по наиболее важным вопросам и сохранением за своими представителями значимых властных постов. В неблагоприятном экономическом контексте середины 1990-х гг. такая стратегия не сулила дивидендов, зато издержки оказались весьма существенными. Не имея возможности влиять на принятие значимых решений, 
«либералы» в глазах избирателей несли ответственность за неудачи правительства, в силу чего их массовая поддержка снижалась, а влияние в коридорах власти ослабло. Напротив, «Яблоко», изначально возникнув как пестрый конгломерат политиков, смогло представить свои программные принципы и установки как демократическую оппозицию ельцинскому режиму и привлечь на свою сторону не слишком большое, но весьма заметное число избирателей. Последующие усилия, предпринятые лидером «Яблока» Г.А. Явлинским и рядом других деятелей, позволили превратить «Яблоко» в полноценную политическую партию [Hale 2004; White 2006; Gel'man 2005].

Таким образом, «либералы» и «демократы» стали конкурентами в политической борьбе, и их отношения оказались весьма напряженными. Связано это было с тем, что институциональные и политические стимулы к коалиционной политике российских партий были весьма невелики даже среди идейно близких партий: единственным возможным вариантом выстраивания коалиций стало «недружественное поглощение» более мелких образований более крупными [Щербак 2002]. Разность потенциалов ВР-ДВР-СПС и «Яблока» была не настолько значительна для подобного поглощения, а претензии более близкого к Кремлю и обладавшего большими ресурсами ДВР на то, чтобы задушить в своих объятиях «Яблоко», встречали резкую критику со стороны «демократов» [Явлинский 1995]. $\mathrm{C}$ точки зрения позиционирования обеих партий по наиболее значимым вопросам их подходы отличались весьма кардинально: в ходе референдума декабря 1993 г. «либералы» поддержали президентский проект конституции и активно выступили за переизбрание Б.Н. Ельцина; «демократы», напротив, отказались поддержать проект Конституции [Шейнис 2005, т. 2], а в ходе президентских выборов 1996 г. Г.А. Явлинский сам баллотировался на пост главы государства, и во втором туре «Яблоко» отказалось поддержать Б.Н. Ельцина.

С точки зрения стратегического позиционирования «демократы» из «Яблока» разрывались между сближением с «либералами» и максимальным дистанцированием от них. Предпринимавшиеся время от времени попытки сдвига «Яблока» в сторону ниши «демократической левой» партии поддержки «демократов» так и не получили: «Яблоку» не удалось однозначно сформулировать идейную альтернативу «либералам» в части предлагаемого ими политического курса. Позиции партии в целом были несколько более левыми, чем у конкурентов-«либералов», особенно отличаясь от них в части подходов к приватизации [Dmitriev 1999]. Но эти различия не всегда были понятны как сторонникам обоих течений, так и рядовым активистам, из-за чего многие разногласия «демократов» и «либералов» воспринимались наблюдателями лишь как проявления персональных конфликтов. В свою очередь «либералы» также не представляли собой монолитный блок, и их внутренние противоречия со временем усугубились: сегодня трудно себе представить, что этатист и апологет концепции «русского мира» С.Ю. Глазьев и радикальный критик политики российских властей А.Н. Илларионов в конце 1980-х - начале 1990-х гг. были соратниками в рамках «команды Гайдара». И даже когда программные позиции «либералов» оставались более или менее прежними в отношении экономической политики, в практической деятельности они не всегда следовали согласно базовым принципам.

Хотя на думских выборах 1995 г. ДВР потерпел сокрушительное поражение, «либералы» не только не выбыли из высшей лиги российской политики, 
но и упрочили влияние благодаря активному участию в пестрой проельцинской коалиции на президентских выборах 1996 г. и последующему контролю над рядом правительственных постов [Авен 2018; Freeland 2000; Hoffman 2002]. После финансового кризиса 1998 г., вина за который была возложена на «либералов», они сумели проявить организационную сплоченность и сформировать новую коалицию, успешно выступившую на выборах 1999 г. как «Союз правых сил». Примечательно, что к этому моменту «либералы» стратегически отказались от присвоения наследия «демократов» и позиционировали себя как «правые», солидаризируясь в ходе кампании с В.В. Путиным. Благодаря поддержке со стороны Кремля им удалось вернуться в парламент и одержать принципиальную победу над конкурентами из «Яблока». «Демократы» же, в свою очередь, столкнулись с глубоким внутренним кризисом: «Яблоко» выступало против инициатив Кремля, систематически отказываясь выбирать «из двух зол», и в результате стало оппозицией, в принципе неспособной претендовать на участие в правительстве, что препятствовало расширению его электоральной базы. В глазах своих сторонников «Яблоко» не выглядело партией, способной реализовать собственную программу, и попытки переломить ситуацию успеха не имели, а неудачный для «Яблока» исход выборов 1999 г. продемонстрировал иллюзорность электоральных перспектив «демократов» [Gel'man 2005].

В результате в 2000-2003 гг. как «либералы», так и «демократы» оказались в не слишком выигрышной роли полуоппозиции. Для «либералов» это означало, что Кремль лишь тактически нуждался в союзе с ними, и дивиденды от претензий на роль младшего партнера для СПС были незначительными. В тот же период кризис «Яблока» усугубился: его ряды покинули несколько известных думских депутатов и региональных активистов, прежние идеи «демократов» стали пользоваться меньшим спросом у избирателей, а новые идеи не предлагались. На этом фоне СПС, который выступал «мотором» новой волны либеральных реформ начала 2000-х гг. и, казалось бы, вновь воспрял духом, предпринял несколько попыток задушить в своих объятиях «демократов» из «Яблока». В ходе думских выборов 2003 г. «либералы» вели борьбу не столько за голоса избирателей, сколько за устранение «яблочных» конкурентов, которые отвечали им тем же, что подрывало позиции обоих участников конфликта. Эти выборы, по сути, стали «лебединой песнью» для обеих партий: как «либералы», так и «демократы» не попали в Государственную Думу четвертого созыва, после чего заместитель главы президентской администрации В.Ю. Сурков заявил об исчерпанности исторической миссии этих партий в России.

Последующие события продемонстрировали глубокий упадок обоих политических лагерей: «либералы» пережили размежевание в своей среде на «системных» лоялистов Кремлю и «несистемных» критиков Кремля, сблизившихся с «демократами», которые, в свою очередь, все более политически маргинализовались на фоне усиления авторитарных тенденций в стране. Их противостояние со временем становилось менее значимым в глазах широкой публики, особенно по мере выхода на политическую арену нового поколения оппозиционных политиков [Gel'man (2) 2015]. Однако остается невыясненным, каковы же причины и механизмы идейной борьбы между «либералами» и «демократами» в России, ее влияние на траектории трансформации в стране и перспективы реформистских идей в будущем. 


\section{Вместо заключения: взлет и падение реформистских идей}

Почему одни идеи оказывают воздействие на процессы общественных преобразований, а другие нет? Ответ на этот вопрос может быть дан сквозь призму как спроca, так и предложения на рынке идей. Потребность в них возрастает в периоды, когда ситуация в тех или иных обществах воспринимается элитами и общественным мнением как кризисная, но по мере исчерпания неопределенности этот спрос может падать, при этом оставляя не у дел их производителей и распространителей. С этой точки зрения взлет реформистских лозунгов во времена перестройки и упадок «либералов» и «демократов» в 2000-е гг. могли быть объяснены как следствие динамики на стороне идейного спроса. До начала перестройки интерес к альтернативным концептам был искусственно ограничен, а после посткоммунистической трансформации по мере консолидации нового политико-экономического порядка в России предложения «либералов» и «демократов» перестали быть востребованы. Новый всплеск спроса на идейном рынке в 2010-е гг. повлек за собой выход на авансцену концепций, далеких от модернизации, в то время как демократии и рыночным реформам места на этом рынке попросту не нашлось.

Однако для анализа борьбы между разными реформистскими течениями изучение спроса на идейном рынке должно быть дополнено оценкой предложения с точки зрения не только содержания идей как таковых, но и с учетом действий их производителей и распространителей. Хотя предложение концепций не всегда напрямую связано с их воздействием на текущую повестку дня [Стедмен-Джоунз 2017], но без оформленных программных представлений и активных усилий различных агентов по их продвижению говорить о влиянии концепций очевидно не приходится. Предложение со стороны «демократов» носило слишком общий характер и в целом являлось слабо продуманным, а его производители и распространители не готовы были к тому, чтобы удовлетворить внезапно возникший спрос. Заявка со стороны «либералов» хотя и оказалась более целостной, однако она концентрировалась лишь на одном важнейшем аспекте посткоммунистической трансформации (строительстве рыночной экономики) и была «заточена» на одноразовое применение в конкретном контексте реформ. И «демократы», и в особенности «либералы» в своем предложении идей и в их практическом воплощении в жизнь ориентировались не на широкие, а, скорее, на узкие группы интересов, что вело к утрате доверия со стороны элит и общественности. И хотя «либералы» благодаря удачному для них стечению обстоятельств (смена поколений на фоне неудовлетворенности предложениями «демократов») смогли в начале 1990-х гг. одержать тактическую победу на рынке реформистских идей, в среднесрочной перспективе как «либералы», так и «демократы» потерпели тяжелое поражение.

Другим важным уроком российского опыта конца 1980-х - начала 2000-х гг. служит тот факт, что в борьбе важны не только и не столько сами концепции как таковые, сколько их принятие/непринятие элитами и общественностью, помноженное на восприятие фигур производителей и распространителей этих идей. «Демократы»-шестидесятники проиграли своим более молодым, более образованным и более современным конкурентам - «либералам»-семидесятникам. Но и тем, в свою очередь, не удалось стать «властителями дум» значительной части интеллектуалов, не говоря уже о широкой общественности (хотя часть из них в 1990-е гг. 
и оказала влияние на позиции российских элит), несмотря на то, что они сыграли немалую роль в подготовке и принятии значимых решений (это влияние «либералов» не утрачено и по сей день, но оно весьма незначительно).

Поражение «демократов» и «либералов» отнюдь не говорит о том, что их идеи оказались бесполезны для трансформации России в конце XX в. Тот факт, что наша страна смогла построить рыночную экономику и провозгласила себя демократией, декларировав (но не воплотив в жизнь) принципы политических и гражданских свобод, во многом стал следствием продвижения реформистских программ. Хотя их производители и распространители конца 1980-х - начале 1990-х гг. вряд ли нашли бы в России начала 2020-х гг. воплощение своих замыслов в жизнь, тем не менее реформистские идеи во многом способствовали выходу нашей страны из того тупика, в котором она находилась на начало перестройки, и в немалой мере помогли необратимости подобного результата. Однако этот факт сам по себе не предотвращает попадание в новые тупики в будущем, и к такому развитию событий в России начала XXI в. ни «демократы», ни «либералы» готовы не были.

К началу 2020-х гг. шестидесятники окончательно сошли с российской сцены, да и от сменивших их семидесятников трудно ожидать нового предложения на идейном рынке. Но что нового могут принести в борьбу идей в России новые поколения «демократов» и «либералов» в отличие от своих предшественников? Окажутся ли их программные представления востребованы в обозримом будущем, и если да, то в каком ключе? Ответ на эти вопросы выглядит неочевидным. Хотя «демократы» после краха 2000-х гг. более или менее успешно нашли себя в правозащитной деятельности, сохранив ядро своих производителей и распространителей, «нишевый» характер их лозунгов, хотя и позволяет воспроизводить прежние идеалы, однако объективно оставляет немного шансов на то, что при появлении в России нового спроса на демократизацию сами «демократы» окажутся в этом качестве востребованы. Спорными выглядят и попытки трансформировать идеи «демократов» посредством прививки популизма, предпринимаемые в 2010-е гг. А.А. Навальным [Lassila 2016]. Хотя эти шаги призваны стимулировать новый спрос на идейном рынке, остается неясным, в какой мере соответствующее предложение окажется целостным и успешным, или же оно окажется лишь политтехнологическим приемом в борьбе против нынешнего режима. Сложнее оценить перспективы российских «либералов», чьи идеи (как и их носители) после краткосрочного успеха во многом оказались (справедливо или нет) дискредитированы в восприятии российской общественности. Приход нового поколения не изменил (по крайней мере, в настоящее время) ландшафт в этом политическом лагере, а новые лозунги пока не настолько оформлены, чтобы серьезно претендовать на борьбу за умы и сердца россиян.

Так или иначе, программные подходы к российской модернизации, предложенные «демократами» и «либералами» конца ХХ в., не стоит полностью списывать в архив. В будущем новые попытки продвижения вперед не смогут обойтись без реформистских программ, которые, безусловно, будут отличаться от тех, что определяли ситуацию 20-30 лет назад. От их успеха на идейном рынке во многом будет зависеть повестка дня нового раунда российской трансформации, и от того уроки опыта «демократов» и «либералов» остаются актуальными с точки зрения перспектив России. 


\section{Литература}

Авен П. (2018) Время Березовского. М.: АСТ, Corpus.

Авен П., Кох А. (2013) Революция Гайдара. История реформ 90-х из первых рук. М.: Альпина Паблишер.

Афанасьев Ю. (ред.) (1988) Иного не дано. М.: Прогресс.

Барбакадзе М. (2007) Шестидесятники // Фонд «Либеральная миссия» // http://www.liberal.ru/upload/files/60-desyatniki.pdf

Баткин Л. (1988) Стать Европой // Век ХХ и мир. № 8. С. 30-35.

Буртин Ю. (ред.) (1992) Год после августа: горечь и выбор. М.: Литература и политика.

Васильев С. (2011) Интеллектуальная подготовка реформ 90-х // Фонд Егора Гайдара. 8 декабря $2011 / / \mathrm{http}: / /$ lectures.gaidarfund.ru/articles/1152

Васильев С., Львин Б. (1989) Социальные механизмы экономической реформы и характер переходного процесса // Бородкин Ф., Косалс Л., Рывкина Р. (ред.) (1989) Постижение: социология, социальнаяполитика, экономическая реформа. М.:Прогресс. C. 409-421.

Гайдар Е. (2009) Смуты и институты // Гайдар Е. (2009) Власть и собственность. СПб.: Норма. С. 5-182.

Гельман В., Рыженков С., Белокурова Е., Борисова Н. (2002) Автономия или контроль? Реформа местной власти в городах России, 1991-2001. М., СПб.: Летний сад.

Гельман В., Травин Д. (2013) «Загогулины» российской модернизации: смена поколений и траектории реформ // Неприкосновенный запас. № 4. С. 14-38.

Дерлугьян Г. (2010) А был ли нужен Пиночет? // Эксперт. № 1. С. 78-83.

Жестким курсом (1990) Аналитическая записка // Век ХХ и мир. № 6. С. 15-19.

Заславская Т. (1988) О стратегии социального управления перестройкой // Афанасьев Ю. (ред.) Иного не дано. М.: Прогресс. С. 9-50.

Змеиная горка (2006) // Полит.ру // http://polit.ru/tag/zmeinka

Игрунов В. (2015) Во время ГКЧП произошла революция в самом Ельцине // Lenta.ru. 25 мая 2015 // https://lenta.ru/articles/2015/05/25/igrunov/

Капустин Б.Г. (1995) Либеральная идея и Россия (пролегомены к концепции современного российского либерализма) // Чернышев С. (ред.) Иное: хрестоматия нового российского самосознания. М.: Аргус. С. 125-166// http://ecsocman.hse.ru/data/527/678/1219/067. KAPUSTIN.pdf

Львин Б. (2006) Просили мемуар? // Livejournal.com. 12 декабря 2006 // https://bbb.livejournal.com/1684492.html

Мигранян А., Клямкин И. (1989) Нужна «железная рука»? // Литературная газета. 16 августа 1989.

Найшуль В. (1989) Проблема создания рынка в СССР // Бородкин Ф., Косалс Л., Рывкина Р. (ред.) Постижение: социология, социальная политика, экономическая реформа. М.: Прогресс. С. 441-454.

Радаев В. (1998) Экономическая социология. М.: Аспект-пресс.

Рогов К. (2018) Кризис перехода: Октябрь 1993-го и уроки макроистории // Inliberty.ru. 6 октября 2018 // https://www.inliberty.ru/magazine/issue8/

Сахаров А. (1989) Конституция Союза Советских Республик Европы и Азии (проект народного депутата СССР, академика А.Д. Сахарова) // Конституция Российской Федерации // http://constitution.garant.ru/history/active/1024/

Сигман К. (2014) Политические клубы и перестройка в России: оппозиция без диссидентства. М.: Новое литературное обозрение.

Сонин К. (2007) Реформы и институты: взгляд экономиста // Новое литературное обозрение. № 83 // http://magazines.russ.ru/nlo/2007/83/so25.html

Стедмен-Джоунз Д. (2017) Рождение неолиберальной политики: от Хайека и Фридмана до Рейгана и Тэтчер. М., Челябинск: Социум.

Травин Д. (2018) Особый путь России: от Достоевского до Кончаловского. СПб.: Издательство Европейского университета в Санкт-Петербурге. 
Травин Д., Гельман В., Заостровцев А. (2017) Российский путь: идеи, интересы, институты, иллюзии. СПб.: Издательство Европейского университета в Санкт-Петербурге.

Травин Д., Маргания О. (2011) Модернизация: от Елизаветы Тюдор до Егора Гайдара. М.: АСТ, Астрель.

Улюкаев А. (1995) Либерализм и политика переходного периода в современной России // Мир России. № 2. С. 3-35 // https://mirros.hse.ru/article/view/5495/5882

Черняев А. (2009) Совместный исход (Дневник двух эпох. 1972-1991 годы). М.: РОССПЭН.

Чубайс А. (2008) Куда не уйдет Чубайс // The New Times, 11 февраля 2008 // https://newtimes.ru/articles/detail/4770

Шахназаров Г. (2001) С вождями и без них. М.: Вагриус.

Шейнис В. (2005) Взлет и падение парламента: переломные годы в российской политике. 2 тома. М.: Московский центр Карнеги.

Щербак А. (2002) Коалиционная политика российских партий // Гельман В., Голосов Г., Мелешкина Е. (ред.) Второй электоральный цикл в России, 1999-2000. М.: Весь мир. С. $107-133$.

Явлинский Г. (1995) В расколе демократов трагедии нет // Известия. 13 июля 1995.

Almond G. (1988) Separate Tables: Schools and Sects in Political Science // PS: Political Science and Politics, vol. 21, no 4, pp. 828-842.

Appel H. (2004) A New Capitalist Order: Privatization and Ideology in Russia and Eastern Europe, Pittsburgh: University of Pittsburgh Press.

Appel H., Orenstein M. (2016) Why Did Neoliberalism Triumph and Endure in the Post-Communist World // Comparative Politics, vol. 48, no 3, pp. 313-331.

Åslund A. (1991) Gorbachev's Struggle for Economic Reforms, $2^{\text {nd }}$ ed., Ithaca: Cornell University Press.

Åslund A. (2007) Russia's Capitalist Revolution: Why Market Reforms Succeeded and Democracy Failed, Washington, DC: Peterson Institute for International Economics.

Barnes A. (2006) Owning Russia: The Struggle over Factories, Farms, and Power, Ithaca: Cornell University Press.

Boycko M., Shleifer A., Vishny R. (1995) Privatizing Russia, Cambridge, MA: MIT Press.

Clover C. (2017) Black Wind, White Snow: The Rise of Russia's New Nationalism, New Haven: Yale University Press.

Dawisha K. (2014) Putin's Kleptocracy: Who Owns Russia? New York: Simon and Schuster.

Dmitriev M. (1999) Party Economic Programs and Implications // Primer on Russia's 1999 Duma Elections (eds. McFaul M., Petrov N., Ryabov A., Reicsh E.), Washington, DC: Carnegie Endowment for International Peace, pp. 31-60.

Fish M.S. (1995) Democracy from Scratch: Opposition and Regime in a New Russian Revolution, Princeton: Princeton University Press.

Flikke G. (1999) Patriotic Left-Centrism: the Zigzags of the Communist Party of the Russian Federation // Europe-Asia Studies, vol. 51, no 2, pp. 275-298.

Freeland C. (2000) Sale of the Century: Russia's Wild Rule from Communism to Capitalism, New York: Crown Business.

Frye T. (2010) Building States and Markets after Communism: The Perils of Polarized Democracy, Cambridge: Cambridge University Press.

Frye T. (2017) Property Rights and Property Wrongs: How Power, Institutions, and Norms Shape Economic Conflict in Russia, Cambridge: Cambridge University Press.

Gaidar Y. (2007) Collapse of an Empire: Lessons for Modern Russia, Washington, DC: Brookings Institution Press.

Gel'man V. (2005) Political Opposition in Russia: A Dying Species? // Post-Soviet Affairs, vol. 21, no 3, pp. 226-246.

Gel'man V. (1) (2015) Authoritarian Russia: Analyzing Post-Soviet Regime Changes, Pittsburgh: University of Pittsburgh Press.

Gel'man V. (2) (2015) Political Opposition in Russia: A Troubled Transformation // Europe-Asia Studies, vol. 67, no 2, pp. 177-191.

Gel'man V. (2018) Politics versus Policy: Technocratic Traps of Russia's Policy Reforms // Russian Politics, vol. 3, no 2, pp. 282-304.

Hale H. (2004) Yabloko and the Challenge of Building a Liberal Party in Russia // Europe-Asia Studies, vol. 56, no 7, pp. 993-1020. 
Hale H. (2015) Patronal Politics: Eurasian Regime Dynamics in Comparative Perspective, Cambridge: Cambridge University Press.

Hanson S. (2010) Post-Imperial Democracies: Ideology and Party Formation in Third Republic France, Weimar Germany, and Post-Soviet Russia, Cambridge: Cambridge University Press.

Hellman J. (1998) Winners Take All: The Politics of Partial Reform in Postcommunist Transitions // World Politics, vol. 50, no 2, pp. 203-234.

Hoffman D. (2002) The Oligarchs: Wealth and Power in the New Russia, New York: Public Affairs Books.

Johnson J. (2016) Priests of Prosperity: How Central Bankers Transformed the Postcommunist World, Ithaca: Cornell University Press.

Laruelle M. (2018) Russian Nationalism: Ideologies, Doctrines, and Political Battlefields, Abingdon: Routledge.

Lassila J. (2016) Aleksei Naval'nyi and Populist Re-Ordering of Putin's Stability // Europe-Asia Studies, vol. 68, no 1 , pp. 118-137.

Lukin A. (2000) The Political Culture of the Russian "Democrats", Oxford: Oxford University Press.

McFaul M. (1998) Russia's Choice: The Perils of Revolutionary Democracy // Growing Pains: Russian Democracy and the Election of 1993 (eds. Colton T., Hough J.), Washington, DC: Brookings Institution Press, pp. 115-139.

Miller C. (2016) The Struggle to Save the Soviet Economy: Mikhail Gorbachev and the Collapse of the USSR, Chapel Hill: University of North Carolina Press.

North D.C. (1981) Structure and Change in Economic History, New York: W.W.Norton.

Offe C. (1991) Capitalism by Democratic Design? Democratic Theory Facing the Triple Transition in East Central Europe // Social Research, vol. 58, no 4, pp. 865-892.

Reddaway P., Glinski D. (2001) The Tragedy of Russian Reforms: Market Bolshevism Against Democracy, Washington, DC: United States Institute of Peace.

Sautman B. (1995) The Devil to Pay: the 1989 Debate and the Intellectual Origins of Yeltsin's Soft Authoritarianism // Communist and Post-Communist Studies, vol. 28, no 1, pp. 131-151.

Shleifer A., Treisman D. (2000) Without a Map: Political Tactics and Economic Reform in Russia, Cambridge, MA: MIT Press.

Sokolov B., Inglehart R., Ponarin E., Vartanova I., Zimmerman W. (2018) Disillusionment and Anti-Americanism in Russia: From Pro-American to Anti-American Attitudes // International Studies Quarterly, vol. 62, no 1, pp. 534-547.

Taylor B. (2018) The Code of Putinism, Oxford: Oxford University Press.

Urban M. (1997) The Rebirth of Politics in Russia, Cambridge: Cambridge University Press.

Vujacic V. (1996) Gennadiy Zyuganov and the "Third Road" // Post-Soviet Affairs, vol. 12, no 2, pp. 118-154.

White D. (2006) The Russian Democratic Party Yabloko: Opposition in a Managed Democracy, Aldershot: Ashgate.

Yakovlev A. (2006) The Evolution of Business-State Interactions in Russia: From State Capture to Business Capture? // Europe-Asia Studies, vol. 58, no 7, pp. 1033-1056.

Yurchak A. (2005) Everything Was Forever, Until It Was No More: The Last Soviet Generation, Princeton: Princeton University Press.

Zubok V. (2009) Zhivago's Children: Last Russian Intelligentsia, Cambridge, MA: Harvard University Press.

Zweynert J. (2018) When Ideas Fail: Economic Thought, the Failure of Transition, and the Rise of Institutional Instability in Post-Soviet Russia, Abingdon: Routledge. 


\title{
"Liberals" versus "Democrats": Ideational Trajectories of Russia's Post-Communist Transformation
}

\author{
V. GEL'MAN*
}

\begin{abstract}
*Vladimir Gel'man - PhD in Politics, Professor, European University at St. Petersburg; University of Helsinki. Address: 6/1, Gagarinskaya St., Saint Petersburg, 191187, Russian Federation. E-mail: vgelman@eu.spb.ru

Citation: Gel'man V. (2020) "Liberals" versus "Democrats": Ideational Trajectories of Russia's Post-Communist Transformation. Mir Rossii, vol. 29, no 1, pp. 53-79 (in Russian). DOI: 10.17323/1811-038X-2020-29-1-53-79
\end{abstract}

\begin{abstract}
This article analyzes the struggle between the contradictory ideas of modernization in Russia's post-Communist transformation in the 1980s and 1990s. I concentrate on the genesis and evolution of two major ideational trends, namely, the "liberal" (which prioritized market economic reforms) and the "democratic" (which prioritized political freedoms and democratic institution-building). What are the sources of the contradiction between these trends? What are the causes and consequences of their divergence? And how did these ideas affect the outcomes of Russia's transition? I argue that the ideational struggle and the political conflict between Russian "liberals" and "democrats" is rooted in the intergenerational tensions between the "sixtiers" and the "seventhiers", whose political attitudes, life experience and perceptions of the country's problems were very different in many respects. While the democrats (the representatives of the sixtiers) had a very limited understanding of the market reforms and in fact underestimated the importance of the economic aspects of transition, the liberals (seventhiers) remained skeptical about democratization being an obstacle to market reforms. These differences in the priorities and the perceptions, inflated through the political conflict of the 1990s, greatly contributed to the major political schism between the two camps of Russia's reformers. As a result, both the liberals and the democrats failed politically, which had a strong negative impact on the political and ideational landscape in twenty-first century Russia.
\end{abstract}

Key words: political ideas, post-Communist transformation, Russia, liberalism, democracy, market reforms

\section{References}

Afanasyev Y. (ed.) (1988) Inogo ne dano [No Other Way], Moscow: Progress.

Almond G. (1988) Separate Tables: Schools and Sects in Political Science. PS: Political Science and Politics, vol. 21, no 4, pp. 828-842. 
Appel H. (2004) A New Capitalist Order: Privatization and Ideology in Russia and Eastern Europe, Pittsburgh: University of Pittsburgh Press.

Appel H., Orenstein M. (2016) Why Did Neoliberalism Triumph and Endure in the Post-Communist World. Comparative Politics, vol. 48, no 3, pp. 313-331.

Åslund A. (1991) Gorbachev's Struggle for Economic Reforms, $2^{\text {nd }}$ ed., Ithaca: Cornell University Press.

Åslund A. (2007) Russia's Capitalist Revolution: Why Market Reforms Succeeded and Democracy Failed, Washington, DC: Peterson Institute for International Economics.

Aven P. (2018) Vremya Berezovskogo [Berezovsky's Time], Moscow: AST, Korpus.

Aven P., Kokh A. (2013) Revolutsiya Gaidara: Istoriya reform 90-kh iz pervykh ruk [Gaidar's Revolution: the First-Hand Account of History of Reforms of the 1990s], Moscow: Alpina Publishers.

Barkabadze S. (2007) Shestidesyatniki [The Sixtiers]. Fond "Liberal'naya Missiya". Available at: http://www.liberal.ru/upload/files/60-desyatniki.pdf, accessed 31.10.2019.

Barnes A. (2006) Owning Russia: The Struggle over Factories, Farms, and Power, Ithaca: Cornell University Press.

Batkin L. (1988) Stat' Evropoi [Becoming Europe]. Vek XX i mir, no 8, pp. 30-35.

Boycko M., Shleifer A., Vishny R. (1995) Privatizing Russia, Cambridge, MA: MIT Press.

Burtin Y. (ed.) (1992) God posle avgusta: gorech' $i$ vybor [The Year after August: Bitterness and Choice], Moscow: Literatura i politika.

Chernyaev A. (2009) Sovmestnyj iskhod (Dnevnik dvukh epokh, 1972-1991) [The Joint Exodus: Diary of Two Eras, 1972-1991], Moscow: ROSSPEN.

Chubais A. (2008) Kuda ne uidet Chubais [Where Chubais Will Not Exit]. The New Times, February 11, 2008. Available at: https://newtimes.ru/articles/detail/4770, accessed 31.10.2019.

Clover C. (2017) Black Wind, White Snow: The Rise of Russia's New Nationalism, New Haven: Yale University Press.

Dawisha K. (2014) Putin's Kleptocracy: Who Owns Russia? New York: Simon and Schuster.

Derulugian G. (2010) A byl li nuzhen Pinochet? [Whether Pinochet Was Necessary?]. Expert, no 1 , pp. $78-83$.

Dmitriev M. (1999) Party Economic Programs and Implications. Primer on Russia's 1999 Duma Elections (eds. McFaul M., Petrov N., Ryabov A., Reicsh E.), Washington, DC: Carnegie Endowment for International Peace, pp. 31-60.

Fish M.S. (1995) Democracy from Scratch: Opposition and Regime in a New Russian Revolution, Princeton: Princeton University Press.

Flikke G. (1999) Patriotic Left-Centrism: the Zigzags of the Communist Party of the Russian Federation. Europe-Asia Studies, vol. 51, no 2, pp. 275-298.

Freeland C. (2000) Sale of the Century: Russia's Wild Rule from Communism to Capitalism, New York: Crown Business.

Frye T. (2010) Building States and Markets after Communism: The Perils of Polarized Democracy, Cambridge: Cambridge University Press.

Frye T. (2017) Property Rights and Property Wrongs: How Power, Institutions, and Norms Shape Economic Conflict in Russia, Cambridge: Cambridge University Press.

Gaidar Y. (2007) Collapse of an Empire: Lessons for Modern Russia, Washington, DC: Brookings Institution Press.

Gaidar Y. (2009) Smuty i instituty [Troubles and Institutions]. Gaidar Y. (2009) Vlast' i sobstvennost'[Power and Property], Saint Petersburg: Norma, pp. 5-182.

Gel'man V. (2005) Political Opposition in Russia: A Dying Species? Post-Soviet Affairs, vol. 21, no 3, pp. 226-246.

Gel'man V. (1) (2015) Authoritarian Russia: Analyzing Post-Soviet Regime Changes, Pittsburgh: University of Pittsburgh Press.

Gel'man V. (2) (2015) Political Opposition in Russia: A Troubled Transformation. Europe-Asia Studies, vol. 67, no 2, pp. 177-191.

Gel'man V. (2018) Politics versus Policy: Technocratic Traps of Russia's Policy Reforms. Russian Politics, vol. 3, no 2, pp. 282-304. 
Gel'man V., Ryzhenkov S., Belokurova E., Borisova N. (2002) Avtonomiya ili kontrol'? Reforma mestnoi vlasti v gorodakh Rossii, 1991-2001 [Autonomy or Control? Local Government Reforms in Russia's Cities, 1991-2001], Moscow, Saint Petersburg: Letnij sad.

Gel'man V., Travin D. (2013) «Zagoguliny» rossiiskoj modernizatsii: smena pokolenij i traektorii reform [Zigzags of Russian Modernization: Generational Changes and Trajectories of Reforms]. Neprikosnovennyj zapas, no 4, pp. 14-38.

Hale H. (2004) Yabloko and the Challenge of Building a Liberal Party in Russia. Europe-Asia Studies, vol. 56, no 7, pp. 993-1020.

Hale H. (2015) Patronal Politics: Eurasian Regime Dynamics in Comparative Perspective, Cambridge: Cambridge University Press.

Hanson S. (2010) Post-Imperial Democracies: Ideology and Party Formation in Third Republic France, Weimar Germany, and Post-Soviet Russia, Cambridge: Cambridge University Press.

Hellman J. (1998) Winners Take All: The Politics of Partial Reform in Postcommunist Transitions. World Politics, vol. 50, no 2, pp. 203-234.

Hoffman D. (2002) The Oligarchs: Wealth and Power in the New Russia, New York: Public Affairs Books.

Igrunov V. (2015) Vo vremya GKCHP proizoshla revolyutsiya v samom Yeltsine [During the 1991 Coup Yeltsin Experienced a Revolution within Himself]. Lenta.ru, May 25, 2015. Available at: https://lenta.ru/articles/2015/05/25/igrunov/, accessed 31.10.2019.

Johnson J. (2016) Priests of Prosperity: How Central Bankers Transformed the Postcommunist World, Ithaca: Cornell University Press.

Kapustin B. (1995) Liberal'naya ideya i Rossiya (prolegomeny k kontseptsii sovremennogo rossiiskogo liberalizma) [The Liberal Idea in Russia: Prolegomens to the Concept of Modern Russian Liberalism]. Inoe: khrestomatiya novogo rossijskogo samosoznaniya [The Other: A Reader in New Russian Self-Consciousness] (ed. Chernyshev S.), Moscow: Argus, pp. 125-166. Available at: http://ecsocman.hse.ru/data/527/678/1219/067.KAPUSTIN.pdf, accessed 31.10.2019.

Laruelle M. (2018) Russian Nationalism: Ideologies, Doctrines, and Political Battlefields, Abingdon: Routledge.

Lassila J. (2016) Aleksei Naval'nyi and Populist Re-Ordering of Putin's Stability. Europe-Asia Studies, vol. 68, no 1, pp. 118-137.

Lukin A. (2000) The Political Culture of the Russian "Democrats”, Oxford: Oxford University Press.

Lvin B. (2006) Prosili memuar? [You Requested a Memoir?]. Livejournal.com, December 12, 2006. Available at: https://bbb.livejournal.com/1684492.html, accessed 31.10.2019.

McFaul M. (1998) Russia's Choice: The Perils of Revolutionary Democracy. Growing Pains: Russian Democracy and the Election of 1993 (eds. Colton T., Hough J.), Washington, DC: Brookings Institution Press, pp. 115-139.

Migranyan A., Klyamkin I. (1989) Nuzhna zheleznaya ruka? [Is Iron Fist Needed?]. Literaturnaya gazeta, August 16, 1989.

Miller C. (2016) The Struggle to Save the Soviet Economy: Mikhail Gorbachev and the Collapse of the USSR, Chapel Hill: University of North Carolina Press.

Naishul V. (1989) Problema sozdaniya rynka v SSSR [The Problem of Market Building in the USSR]. Postizhenie: sotsiologiya, sotsial'naya politika, ekonomicheskaya reforma [Comprehension: Sociology, Social Policy, Economic Reforms] (eds. Borodkin F., Kosals L., Ryvkina R.), Moscow: Progress, pp. 441-454.

North D.C. (1981) Structure and Change in Economic History, New York: W.W. Norton.

Offe C. (1991) Capitalism by Democratic Design? Democratic Theory Facing the Triple Transition in East Central Europe. Social Research, vol. 58, no 4, pp. 865-892.

Radaev V. (1998) Ekonomicheskaya sotsiologiya [Economic Sociology], Moscow: Aspekt-press. Reddaway P., Glinski D. (2001) The Tragedy of Russian Reforms: Market Bolshevism Against Democracy, Washington, DC: United States Institute of Peace.

Rogov K. (2018) Krizis perekhoda: Oktyabr' 1993 i uroki makroistorii [The Crisis of Transition: October 1993 and Lessons of Macro-History]. Inliberty.ru, October 6, 2018. Available at: https://www.inliberty.ru/magazine/issue8/, accessed 31.10.2019. 
Sakharov A. (1989) Konstitutsiya Soyuza Sovetskikh Respublik Evropy i Azii (proekt narodnogo deputata SSSR, akademika A.D.Sakharova) [The Constitution of the Union of Soviet Republics of Europe and Asia (The Project of Academician Andrey Sakharov)]. Constitution of the Russian Federation. Available at: http://constitution.garant.ru/history/active/1024/, accessed 31.10.2019.

Sautman B. (1995) The Devil to Pay: the 1989 Debate and the Intellectual Origins of Yeltsin's Soft Authoritarianism. Communist and Post-Communist Studies, vol. 28, no 1, pp. 131-151.

Scherbak A. (2002) Koalitsionnaya politika rossijskikh partii [Coalition Politics of Russian Parties]. Vtoroj elektoral'nyj tsikl v Rossii [The Second Electoral Cycle in Russia, 1999-2000] (eds. Gel'man V., Golosov G., Meleshkina E.), Moscow: Ves' mir, pp. 107-133.

Shakhnazarov G. (2001) S vozhdyami i bez nikh [With Leaders and Without Them], Moscow: Vagrius.

Sheinis V. (2005) Vzlet i padenie parlamenta: perelomnye gody v rossiskoi politike [The Rise and Decline of Parliament: Breakthrough Years in Russian Politics], Moscow: Carnegie Moscow Center, 2 vols.

Shleifer A., Treisman D. (2000) Without a Map: Political Tactics and Economic Reform in Russia, Cambridge, MA: MIT Press.

Sigman C. (2014) Politicheskie kluby i perestrojka v Rossii: oppozistiya bez dissidentstva [Political Clubs and Perestroika in Russia: Opposition without Dissent], Moscow: Novoe literaturnoe obozrenie.

Sokolov B., Inglehart R., Ponarin E., Vartanova I., Zimmerman W. (2018) Disillusionment and Anti-Americanism in Russia: From Pro-American to Anti-American Attitudes. International Studies Quarterly, vol. 62, no 1, pp. 534-547.

Sonin K. (2007) Reformy i instituty: vzglyad ekonomista [Reforms and Institutions: An Economist's View]. Novoe literaturnoe obozrenie, no 83. Available at: http://magazines.russ.ru/nlo/2007/83/so25.html, accessed 31.10.2019.

Stedman Jones D. (2017) Rozhdenie neoliberal'noj politiki: ot Hayeka do Friedmana do Reagana $i$ Thatcher [Masters of the Universe: Hayek, Friedman, and the Birth of Neoliberal Politics], Moscow, Chelyabinsk: Sotsium.

Taylor B. (2018) The Code of Putinism, Oxford: Oxford University Press.

Travin D. (2018) Osobyj put'Rossii: ot Dostoevskogo do Konchalovskogo [Russia's Sonderweg: From Dostoevsky to Konchalovsky], Saint Petersburg: European University at St. Petersburg Press.

Travin D., Gel'man V., Zaostrovtsev A. (2017) Rossiiskij put': idei, interesy, instituty, illyuzii [The Russian Path: Ideas, Interests, Institutions, and Illusions], Saint Petersburg: European University at St. Petersburg Press.

Travin D., Marganiya O. (2011) Modernizatsiya ot Elizavety Tyudor do Egora Gaidara [Modernization from Elizabeth Tudor to Yegor Gaidar], Moscow: AST, Astrel.

Ulyukaev A. (1995) Liberalizm i politika perkhodnogo perioda V Rossii [Liberalism and Politics of Transition in Russia]. Mir Rossii, no 2, pp. 3-35. Available at: https://mirros.hse.ru/article/view/5495/5882, accessed 31.10.2019.

Urban M. (1997) The Rebirth of Politics in Russia, Cambridge: Cambridge University Press.

Vasilyev S. (2011) Intellektual'naya podgotovka reform 90-kh [The Intellectual Preparation of Reforms of the 1990s]. Yegor Gaidar Foundation, December 8, 2011. Available at: http://lectures.gaidarfund.ru/articles/1152, accessed 31.10.2019.

Vasilyev S., Lvin B. (1989) Sotsial'nye mekhanizmy ekonomicheskoj reformy i kharakhter perekhodnogo protsessa [Social Mechanisms of the Economic Reforms and the Mode of Transition]. Postizhenie: sotsiologiya, sotsial'naya politika, ekonomicheskaya reforma [Comprehension: Sociology, Social Policy, Economic Reforms] (eds. Borodkin F., Kosals L., Ryvkina R.), Moscow: Progress, pp. 409-421.

Vujacic V. (1996) Gennadiy Zyuganov and the "Third Road". Post-Soviet Affairs, vol. 12, no 2, pp. $118-154$.

White D. (2006) The Russian Democratic Party Yabloko: Opposition in a Managed Democracy, Aldershot: Ashgate.

Yakovlev A. (2006) The Evolution of Business-State Interactions in Russia: From State Capture to Business Capture? Europe-Asia Studies, vol. 58, no 7, pp. 1033-1056. 
Yavlinsky G. (1995) V raskole demokratov tragedii net [There Is No Tragedy in the Democratic Schism]. Izvestiya, July 13, 1995.

Yurchak A. (2005) Everything Was Forever, Until It Was No More: The Last Soviet Generation, Princeton: Princeton University Press.

Zaslavskaya T. (1988) O strategii sotsial'nogo upravleniya perestroikoj [On the Strategy of Social Governance of Perestroika]. Inogo ne dano [No Other Way] (ed. Afanasyev Y.), Moscow: Progress, pp. 9-50.

Zhestkim kursom [On the Tough Course] (1990). Vek XX $i$ mir, no 6, pp. 15-19.

Zmeinaya gorka [The Snake Hill] (2006). Polit.ru. Available at: http://polit.ru/tag/zmeinka, accessed 31.10.2019.

Zubok V. (2009) Zhivago's Children: Last Russian Intelligentsia, Cambridge, MA: Harvard University Press.

Zweynert J. (2018) When Ideas Fail: Economic Thought, the Failure of Transition, and the Rise of Institutional Instability in Post-Soviet Russia, Abingdon: Routledge. 